\title{
POSSIBILITIES OF OBTAINING CADASTRAL PLANS ON LARGE SURFACES USING AERIAL PHOTOGRAMMETRY
}

\author{
Mihai Simon ${ }^{1}$, Loredana Copăcean ${ }^{1,2^{*}}$, Cosmin Popescu $^{1}$, \\ Margareta Măgureanu ${ }^{1}$, Luminiţa Cojocariu ${ }^{1,3}$ \\ ${ }^{1}$ Banat's University of Agricultural Sciences and Veterinary Medicine"King Mihai I of Romania" \\ from Timisoara, 300645, 119, Calea Aradului, Timisoara, Romania \\ ${ }^{2}$ West University of Timișoara, 300223, Bulevardul Vasile Pârvan 4, Timișoara, Romania \\ ${ }^{3}$ Agricultural Research and Development Station Lovrin, 307250, 200, Principala, Lovrin, Romania
}

\begin{abstract}
The importance of research in the field of topo-cadastral or photogrammetry has been revealed by many studies but strictly with reference to the general cadastre without considering the relevance for agriculture: arable land, pastoral space, forests or other uses. In this context, the purpose of the research was to bring "automated" alternatives, remotely, to the preparation, updating or completion of cadastral plans available in the past in analog format, at the level of each ATU. The working methodology consisted of: flying over the territory with WingtraOne photogrammetric equipment, at an altitude of $300 \mathrm{~m}$, generating the orthophotoplan with very high spatial resolution (below $0.5 \mathrm{~m}$ ), vectoring the lands according to the category of use, both in the urban area and outside the commune and the creation of geospatial databases. The obtained results materialized through the topo-cadastral inventory of all the buildings in the analyzed territory (arable land, pastures, hayfields, forests, built spaces, etc.), both as a spatial location (vector format) and as a descriptive database. The application of high precision photogrammetric techniques has a practical application in real estate inventory, especially in the case of large areas, but also a complement to theoretical research in various fields.
\end{abstract}

Keywords: agricultural space, inventory, orthophotoplan, UAS technology.

\section{INTRODUCTION}

According to statistics at the level of the European Union (EU), most member countries, Nordic countries or former USSR countries have completed the registration process of all lands, regardless of their destination and are in the stage of channeling their resources for cadastre maintenance and transition to 3D cadastre. In this sense, these countries have experienced a rapid and consolidated development, because the knowledge of the land situation has given the owners of the property rights confidence and security in the management of the properties.

According to the National Agency for Cadastre and Real Estate Advertising, currently in our country are registered about $44 \%$ of total real estate (May 2021), a small percentage compared to other countries in the EU or outside it. For this reason, it is necessary to know the ways in which other countries with a socio-economic status similar to our country have managed to complete the cadastral works, but also the way of maintenance. 


\section{Current Trends in Natural Sciences}

Vol. 10, Issue 19, pp. 142-150, 2021

https://doi.org/10.47068/ctns.2021.v10i19.019

Current Trends in Natural Sciences (on-line)

ISSN: 2284-953X

Current Trends in Natural Sciences (CD-Rom)

ISSN: 2284-9521

ISSN-L: 2284-9521

ISSN-L: 2284-9521

The National Cartography Center certifies that after 1989, with the change of the communist regime, in Romania attempts were made to obtain cartographic products at national level by means of digital aerial photogrammetry. One of the applications of digital aerial photogrammetry in agriculture in our country is the program "Recognize the plot" through the LPIS system initiated by ANCPI at the request of APIA. During this program, aerial images were taken between 2003-2005 through seven different aerial photogrammetric projects.

Following the acquisition of images, digital orthophotoplanes were drawn up at a scale of 1: 5.000, with a spatial resolution of 0.5 meters, written in the Stereographic 1970 projection system on the Krasovski ellipsoid and with an accuracy of \pm 1.5 meters. The percentage of coverage with orthophotoplans was $98.8 \%$ of the country's land fund, of which about $97.0 \%$ are images that corresponded qualitatively and about $1.8 \%$ were returned due to poor quality (Vorovencii, 2010).

In 2008, 2009, 2010, 2012, 2016 and 2018, other orthophotoplans were made, but which do not cover the entire national territory. Orthophotoplans are used today by ANCPI and subordinate OCPIs for locating and verifying cadastral works prepared by specialists in the field. Their accuracy is getting better, but compared to each other, they show some differences due to the spatial resolution and probably the chosen method of preparation.

Recent years have seen a rapid development in the use of unmanned aerial vehicles (UAVs) to obtain space information (Wallace et al., 2016). The use of drones is ideal for data acquisition at spatial resolutions from 0.5 to $2 \mathrm{~cm}$ (Habib et al., 2016; Simon et al., 2018).

The purpose of the research is to establish the possibilities of using the UAS technique to collect geospatial data and digital photogrammetry in image processing, in order to draw up cadastral plans for the lands in the built-up area and out of town.

The main objective of this study is the elaboration of cadastral plans on large areas, having as support the digital orthophotoplanes, using the two top technologies in the field, UAS and digital photogrammetry.

\section{MATERIALS AND METHODS}

Considering the purpose and objectives of the paper, Zărand locality from Arad county was chosen as the study area (Figure 1).

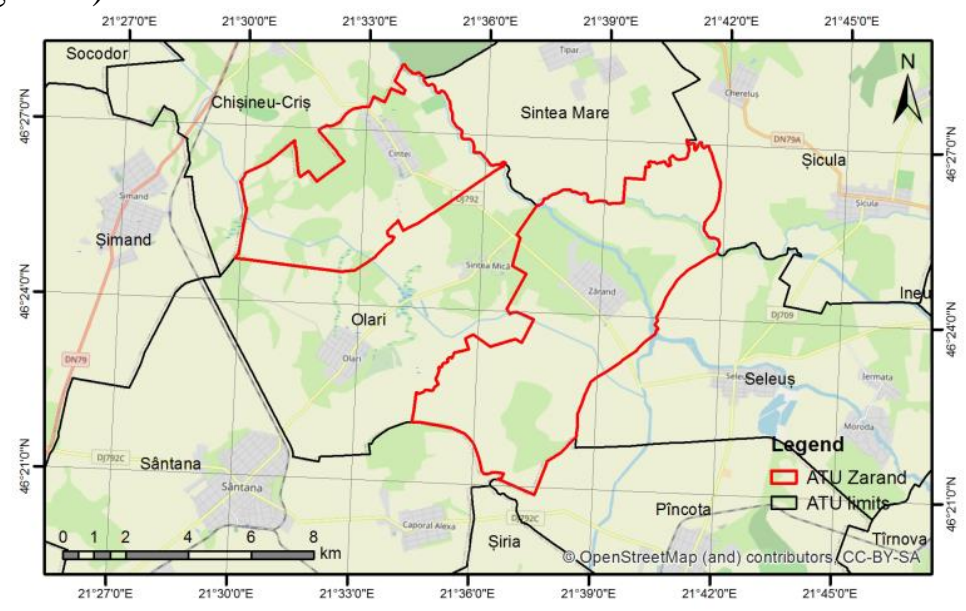

Figure 1. Study area (processing after ANCPI) 
Zărand commune is located in the eastern part of the Crișului Alb Plain, on the Cigher river. It is located $22 \mathrm{~km}$ away from Ineu, $14 \mathrm{~km}$ from Pâncota, $20 \mathrm{~km}$ from Chisinau-Cris and $42 \mathrm{~km}$ away from Arad, according to data published on the website of Zărand City Hall. It is also crossed by the river Cigher, Morilor canal, and to the north is Crișul Alb (Rusu, 2007). Zărand commune has two localities, Zărand and Cintei.

The working methodology, which involves the use of the mentioned technologies, supposes the completion of several stages presented in figure 2.

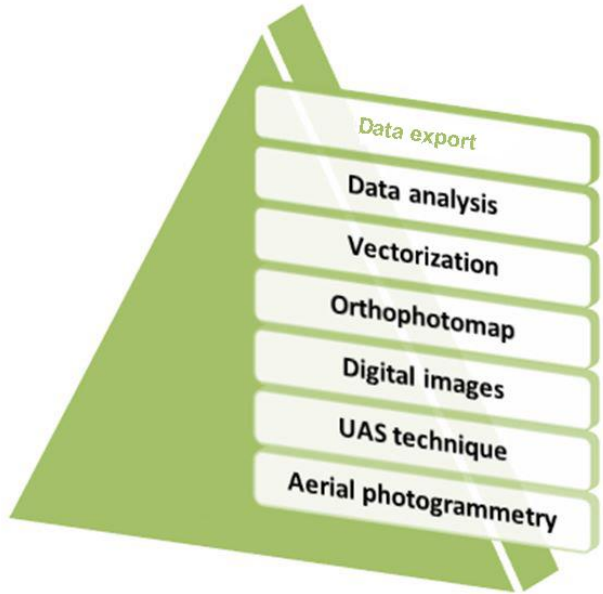

Figure 2. Research methodology

The GNSS positioning technique was used to acquire PPK - RINEX data at 1 second throughout the flight, but also for RTK determinations of control points, these data were collected with the Leica Viva GS14 equipment (Leica Viva GNSS; Smuleac et al., 2015).

A VTOL - WingtraOne tailsitting drone was used to take aerial images. Flight planning and digital imaging was done with the WingtraPilot program, and trajectory correction and bringing them to the 1970 Stereographic system was done with the WingtraHub and TransDatRO programs.

For the processing of digital images and the elaboration of orthophotoplans, a computer with a very powerful processor was used, which allowed the processing of the large amount of information contained in the digital images. Obtaining the orthophotoplan based on digital images was done with the Pix4Dmapper program specialized in image processing to obtain three-dimensional models and orthorectified products (Simon et al., 2018).

The processing and transformation of the products obtained with the help of Pix4Dmapper into other products easier to handle was done using the Global Mapper program, and the elaboration of the cadastral plans was done in AutoCAD (Popescu et al., 2017; Simon et al. 2017).

\section{RESULTS AND DISCUSSIONS}

The new trend in collecting geospatial data used in cadastre for the preparation of orthophotoplans, regardless of land types and category of use, is the use of aerial images taken with drones (Rieke, 2011; Simon et al., 2018), with terrestrial scanners (Smuleac et al., 2012) or satellite images (Cojocariu et al., 2015).

Manyoky et al. (2011) used a Falcon 8 drone equipped with a Panasonic Lumix DMC-LX3 digital camera to take aerial images in order to draw up cadastral plans. They compared the results obtained on the plans drawn up on the basis of aerial images and those drawn up by traditional methods of data acquisition. 


\begin{tabular}{|c|c|}
\hline 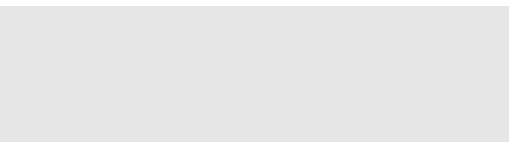 & 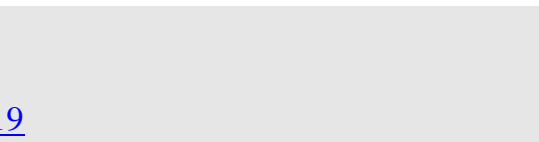 \\
\hline $\begin{array}{l}\text { Current Trends in Natural Sciences (on-line) } \\
\text { ISSN: 2284-953X } \\
\text { ISSN-L: 2284-9521 }\end{array}$ & $\begin{array}{l}\text { Current Trends in Natural Sciences (CD-Rom) } \\
\text { ISSN: } 2284-9521 \\
\text { ISSN-L: } 2284-9521\end{array}$ \\
\hline
\end{tabular}

Cunningham et al. (2011) present the results on the use of drones in cadastre, taking as a study area a rural area of Alaska. The results obtained by them, in many cases close to the accuracies provided by terrestrial measurements, suggest that the use of drones can be an effective alternative.

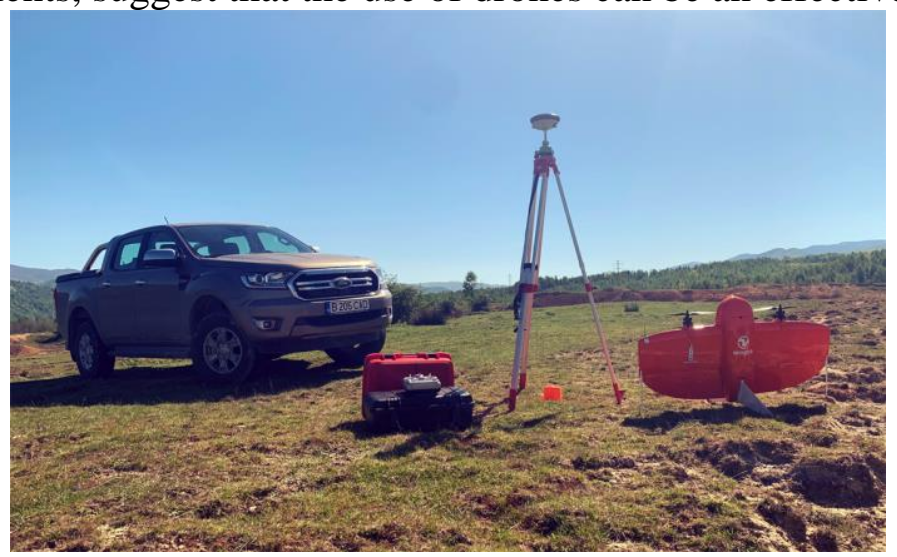

Figure 3. WingtraOne with Leica VivaGS14

The study by van Hinsberg et al. (2013) present the use of drones for taking aerial images based on which the cadastral boundaries of plots with an accuracy of up to $3 \mathrm{~cm}$ were established, similar to the accuracy obtained by classical topographic measurements.

Eyndt and Volkmann (2013) argue that drones can take aerial images with high accuracy and can be an advantageous alternative to replace classical topographic measurements.

The accuracy obtained when delimiting the boundaries of cadastral plots using aerial images taken with UAS is close to the accuracy obtained by classical topographic measurements, some studies showing an accuracy of $10 \mathrm{~cm}$ (Deok-In et al., 2014), below $8 \mathrm{~cm}$ (Sang and Jae, 2016), $5 \mathrm{~cm}$ (Meouche et al., 2016) or less than $5 \mathrm{~cm}$ (Turner et al., 2017; Simon et al., 2018).

To establish the flight parameters, the WingtraPilot application (Figure 4) installed on the drone tablet was used. This application allowed the office to plan the flight path, flight altitude, set the longitudinal and transverse overlays between images or other safety parameters.

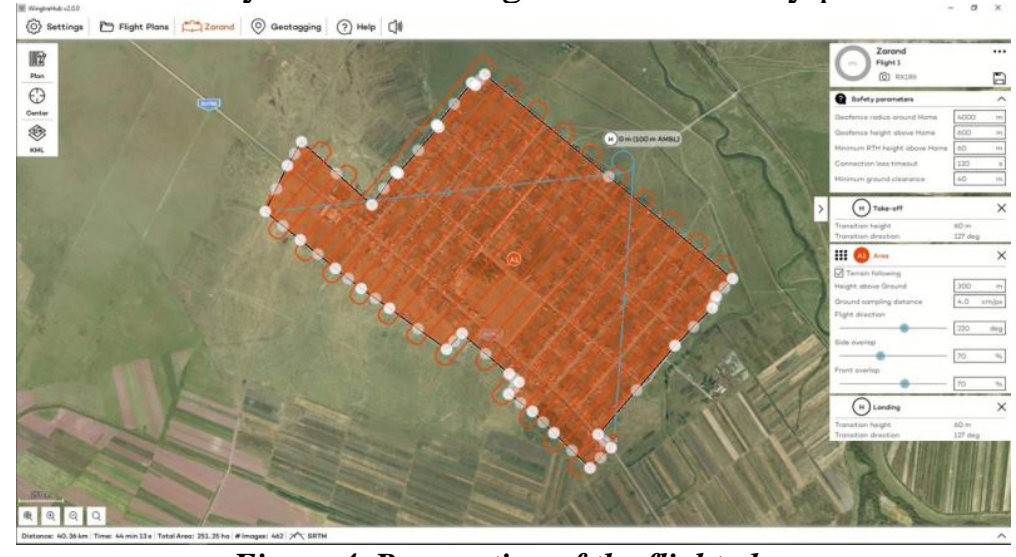

Figure 4. Preparation of the flight plan

The flight was made on March 30, 2021 at an altitude of 300 m above the built-up area of Zărand. The drone flew over the town on a $40 \mathrm{~km}$ route in a time of 44 minutes and covered an area of 251 hectares in 462 images. 
Obtaining an orthophotoplan based on the downloaded digital images involves going through two stages.

The first stage is the correction of the trajectory and its bringing into the Stereographic 1970 system, the stage in which we will use the WingtraHub and TransDatRO programs. At the end of this post-processing we will obtain the new trajectory that we will use in the second stage.

According to the obtained report (Figure 5) the precision of the new trajectory is $2 \mathrm{~cm}$ horizontally and $4 \mathrm{~cm}$ vertically. In this report we also have information about the type of camera used, in our case Sony RX1RII, the number of images used, the coordinates of the reference station or the RINEX data used.

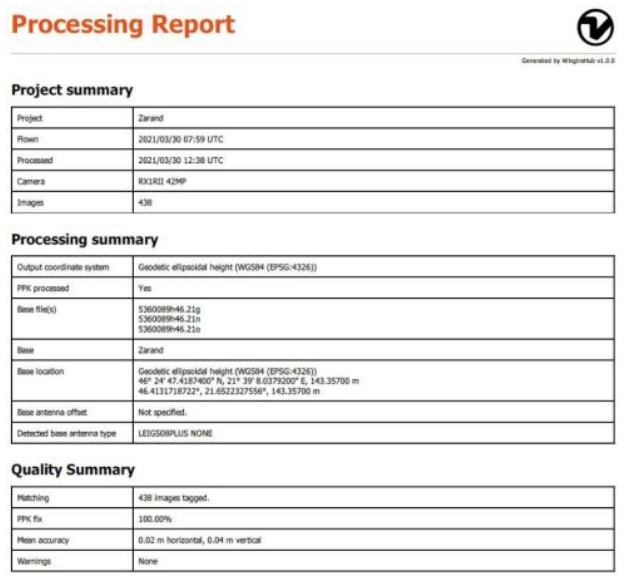

Figure 5. Post-processing report

The second stage is to obtain the orthophotoplan using the Pix4Dmapper program which is based on the SfM type approach. Following this process, we obtained an orthophtoplan with a spatial resolution of $3.85 \mathrm{~cm} /$ pixel on an area of 342 hectares in GeoTiff format. This type of format is very large and difficult to load and use in work environments (CAD or GIS). As such, for an optimal use of the products obtained in terms of the loading time of the files generated after the export, these files were uploaded to the Global Mapper program. The file obtained in Global Mapper was exported with the extension .ecw and covers the entire studied area.

Besides the orthophotoplan, we also obtained the Digital Elevation Model of the studied area together with the point clouds in .las format as well as a quality report (Figure 6).

The accuracy of the orthophotoplan obtained was evaluated by comparing the coordinates of some details determined in the field by means of GNSS technology (corner fences, channel holes, road markings, etc.) and the coordinates of the same details identified on the orthophotoplan (Figure 7). The details used in the precision assessment were spread over the entire area, being covered an area of over $25 \%$ of the total area of the orthophotoplan, exceeding the provisions of the regulations in force (10\% of the area).

Obtaining such a precision, of centimetric order, is an indisputable argument in the use of UAVs for collecting geospatial data for the preparation of orthophotoplans, used in turn as a basis for obtaining the cadastral plan.

The method used to obtain the plans corresponding to the 1980s required the existence of restitution devices with the help of which a general stereomodel could be obtained consisting of the succession of individual stereograms connected to each other and between them and ground by terrestrial reconnaissance at the ends of the flight lane (Chiţea et al., 2003). 
The stereorestitution operation involved the realization of the planimetric restitution, each detail being followed on the optical model with the stereoscopic mark. The altimetry elements were rendered by level curves returned one by one (Rusu, 1974).

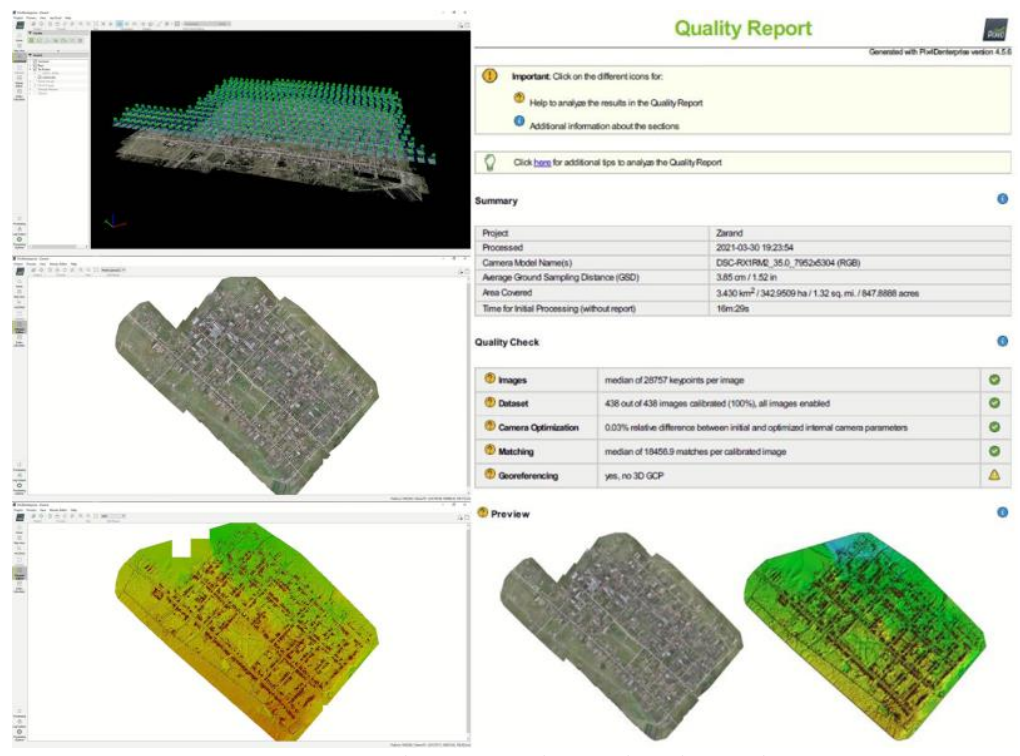

Figure 6. Obtaining the orthophotoplan

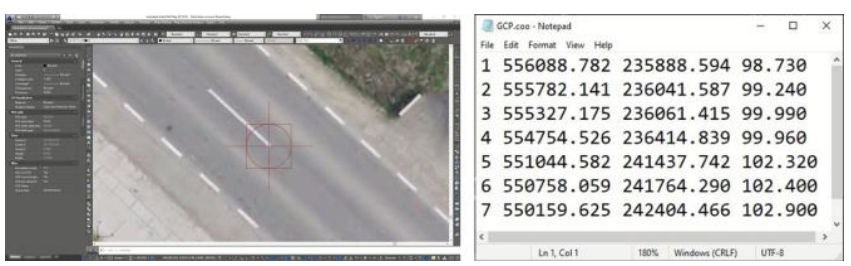

Figure 7. Checking the checkpoints

The elaboration of the cadastral plans for the buildings in the built-up areas of the rural localities has become a topical issue. For this reason and not only, it is necessary to use all technologies to increase the efficiency of cadastral works, which are technically efficient (provide high accuracy) and economically (low maintenance and operating costs).

Given the large areas for which the works are to be carried out, but also their increasing need, the use of UAS technology and digital photogrammetry can be a solution in collecting data and making cadastral plans in digital format.

The realization of the cadastral plan in digital format through the proposed working methodology is the operation of vectoring the details identified on the orthophotoplan (fences, constructions, roads, razors, etc.) followed by the assignment of descriptive data that accompany them (categories of use, destinations of construction, etc.).

Finally, by confronting the graphic part resulting from the vectorization with the descriptive data collected from the field and from the supporting documents regarding the building, the digital cadastral plan can be generated and, consequently, the analog one in different formats. Also, by comparing different data sets, one can express an objective point of view on the quality of previously received works. 


\section{Current Trends in Natural Sciences}

Vol. 10, Issue 19, pp. 142-150, 2021

https://doi.org/10.47068/ctns.2021.v10i19.019

Current Trends in Natural Sciences (on-line)

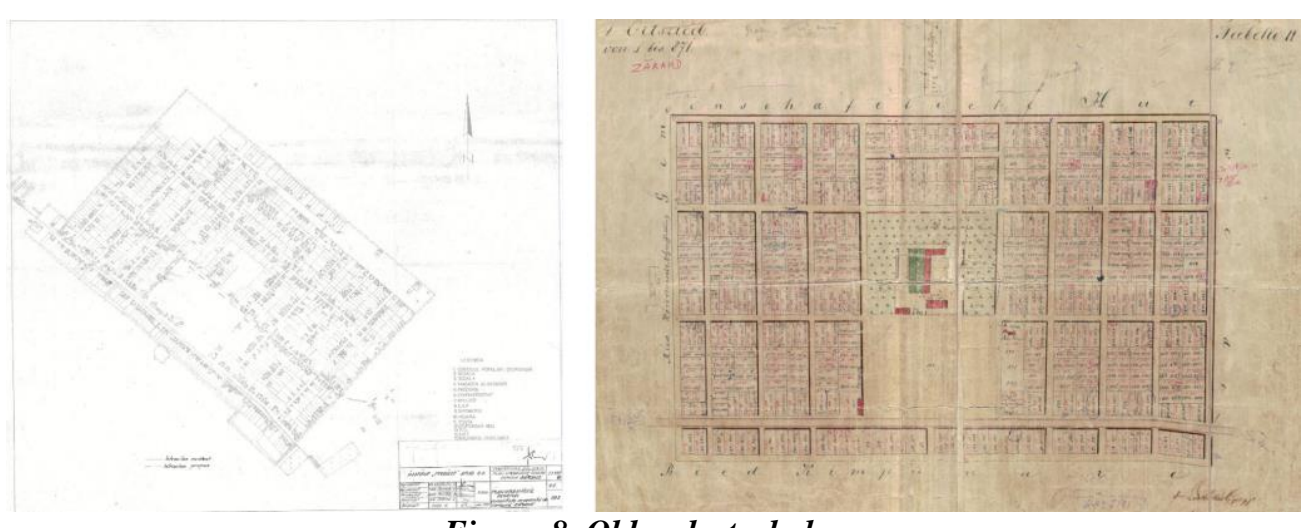

Figure 8. Old cadastral plans

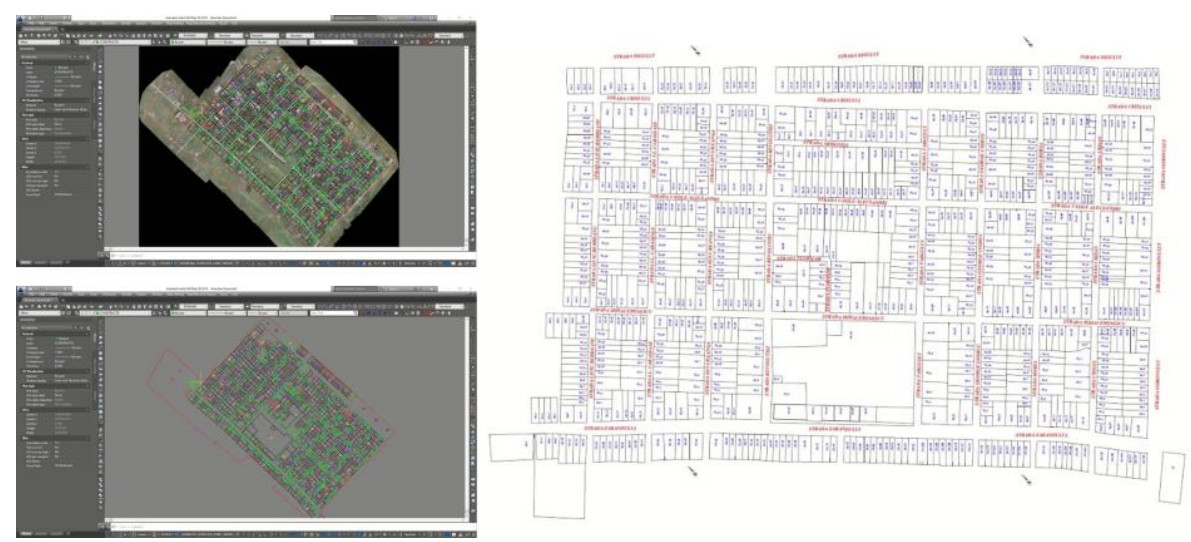

Figure 9. Realization of the cadastral plan

The vectorization of the orthophotoplan was made using the AutoCAD program (Simon et al., 2017) and involved traversing the observable details in the image of the orthophotoplan (fences, constructions, scrapers, etc.) and positioning them through points, lines and polygons. Vectorized details are constructed in image format in the form of segments of known length and direction, respectively in vector form.

\section{CONCLUSIONS}

Obtaining and using an orthophotoplan, as a basis for obtaining cadastral plans, involves going through some stages of field work, but also performing office operations, which require specialized equipment and programs.

The realization of the cadastral plans based on the images acquired with the help of the UAS systems is required more and more given the socio-economic changes that took place in Romania after 1989. As a result of these changes the agricultural and forest lands were fragmented, reaching even up to a few hundred square meters for a building. In this sense, the realization of a digital record, using current techniques of collecting geospatial data from the field, with the help of drones combined with terrestrial techniques, can be a viable alternative.

Digital cadastral plans, as final products of these techniques, made on a large scale and with increasing precision, ensure both the metricity of the product and the possibility of use in various applications. Moreover, by using this technology, one can quickly and efficiently check the state of 
affairs of a certain area and capture the changes that have taken place in order to continuously update the cadastral plans.

\section{REFERENCES}

Chiţea, G., Kiss, A., Vorovencii, I. (2003). Fotogrametrie şi Teledetecţie [Photogrammetry and Remote Sensing]. Editura Universităţii Transilvania, Braşov

Cojocariu, L., Copăcean, L., Horablaga, M.N. (2015). Grassland delineation and representation through remote sensing techniques. Romanian Journal of Grasslands and Forage Crops, 12, 17 - 26

Cunningham, K., Walker, G., Stahlke, E., Wilson, R. (2011). Cadastral audit and assessments using unmanned aerial systems. ISPRS - Int. Arch. Photogramm. Remote Sens. Spatial Inform. Sci. XXXVIII-1/C2, pp. 213-216

Deok-In, K., Yeong-Sun, S., Gihong, K., Chang-Woo, K. (2014). A Study on the Application of UAV for Korean Land Monitoring. Journal of the Korean Society of Surveying Geodesy Photogrammetry and Cartography 32(1), DOI: 10.7848/ksgpc.2014.32.1.29

Eyndt, T., Volkmann, W. (2013). UAS as a tool for surveyors: from tripods and trucks to virtual surveying. GIM Int. 27 , pp. $20-25$

Global Mapper - Getting started guide - https:/www.bluemarblegeo.com/docs/guides/global-mapper-21-getting-startedguide-en.pdf

Habib, A., Han, Y., Xiong, W., He, F., Zhang, Z., Crawford, M. (2016). Automated ortho-rectification of uav-based hyperspectral data over an agricultural field using frame rgb imagery. Remote Sens., 8, 796

Van Hinsberg, W., Rijsdijk, M., Witteveen, W. (2013). UAS for cadastral applications: testing suitability for boundary identification in urban areas. GIM Int. 27, pp. 20-25

Leica Viva Gnss Gs08 plus receiver Datasheet - http://docs.onepointsurvey.com/pdf/Leica-Viva-GS08-NetRoverDatasheet.pdf

Manyoky, M., Theiler, P., Steudler, D., Eisenbeiss, H. (2011). Unmanned aerial vehicle in cadastral applications. Int. Arch. Photogramm. Remote Sens. Spatial Inf. Sci. XXXVIII-1/C22, pp. 57-62

Meouche, R.E., Hijazi, I., Poncet, P.A., Mohammed, A.N., Rezoug, M. (2016). UAV photogrammetry implementation to enhance land surveying, comparisons and possibilities, Conference: $3 \mathrm{~d}$ geo info, Volume: Arch. Photogramm. Remote Sens. Spatial Inf. Sci., XLII-2-W2, pp. 107-114. DOI: 10.5194/isprs-archives-XLII-2-W2-107-2016

National Agency for Cadastre and Real Estate Advertising (ANCPI) - Ministry of Development, Public Works and Administration: https://www.ancpi.ro/grafice-evolutie-cadastru-general/

National Agency for Cadastre and Real Estate Advertising (ANCPI) geospatial database: https://geoportal.ancpi.ro/portal/home/

National Agency for Cadastre and Real Estate Advertising (ANCPI) Transdatro, Rompos - https://rompos.ro/index.php/informatii-tehnice/transdatro

National Cartography Center - National Agency for Cadastre and Real Estate Advertising: https://cngcft.ro/index.php/en/domenii/cartografie-fotogrammetrie

Pix4dmapper Software- User Manual - https://support.pix4d.com/hc/en-us/articles/202557969-Pix4Dmapper-SoftwareManual-Table-View

Popescu, C., Copăcean, L., Cojocariu, L. (2017). Geographic Information Systems, alternative for the „systematic” inventory of lands used as grasslands. Research Journal of Agricultural Science 49 (1), 52-57

Rieke, M., Foerster, T., Geipel, J., Prinz, T. (2011). High-precision positioning and real-time data processing of uavsystems. Int. Arch. Photogramm. Remote Sens. Spat. Inf. Sci., 38, 119-124

Rusu, A. (1974). Topografie cu elemente de geodezie şi fotogrammetrie [Topography with elements of geodesy and photogrammetry]. Editura "CERES”, Bucureşti, 512 pag.

Rusu, R. (2007). Organizarea spaţiului geografic în Banat [Organization of geographical space in Banat], Editura Mirton, Timişoara

Sang, M., Jae, O. (2016). Accuracy of Parcel Boundary Demarcation in Agricultural Area Using UAV-Photogrammetry Journal of the Korean Society of Surveying, Geodesy, Photogrammetry and Cartography, Korean Society of Surveying, Geodesy, Photogrammetry, and Cartography, Volume 34, Issue 1, 2016, pp. 53-62. DOI : 10.7848/ksgpc.2016.34.1.53

Simon, M., Popescu, C.A., Copăcean, L., Cojocariu, L. (2017). CAD and GIS techniques in georeferencing maps for the identification and mapping of meadows in Arad county. Research Journal of Agricultural Science, 49(4) 


\section{Current Trends in Natural Sciences}

Vol. 10, Issue 19, pp. 142-150, 2021

https://doi.org/10.47068/ctns.2021.v10i19.019

Current Trends in Natural Sciences (on-line)

ISSN: 2284-953X

Current Trends in Natural Sciences (CD-Rom)

ISSN: 2284-9521

ISSN-L: 2284-9521

ISSN-L: 2284-9521

Simon, M., Copacean, L., Cojocariu, L. (2018). U.A.V. technology for the detection of spatio-temporal changes of the useful area for forage of grassland. Research Journal of Agriculture Science, 50(4), pp. 332-341

Smuleac, A., Herbei, M., Popescu, C. (2012). Creating the digital terrain model of the USAMVB area using modern technology. Research Journal of Agricultural Science, 44(3), 282-287

Şmuleac, A., Popescu, C., Şmuleac, L., Peptan, C.A. (2015). Processing Lidar Information To Increase Precision In Field Numerical Models. Research Journal of Agricultural Science, 47(2)

Sony, 2021 - https://www.sony.ro/electronics/camere-foto-compacte-cyber-shot/dsc-rx1rm2

Turner, D., Lucieer, A., McCabe, M., Parkes, S., Clarke, I. (2017). Pushbroom hyperspectral imaging from an unmanned aircraft system (UAS) - Geometric processingworkflow and accuracy assessment. Int. Arch. Photogramm. Remote Sens. Spat. Inf. Sci., XLII-2/W6, 379-384

Vorovencii, I. (2010). Fotogrammetrie. Editura MATRIX ROM, Bucureşti 2010, 530 pag.

Wallace, L., Lucieer, A., Malenovský, Z., Turner, D., Vopěnka, P. (2016). Assessment of forest structure using two uav techniques: A comparison of airborne laser scanning and structure from motion (SFM) point clouds. Forests, 7, 62

WingtraHub - Use manual - https://knowledge.wingtra.com/en/install-wingtrahub

Wingtra-One - The professional VTOL drone for mapping and surveying - https://wingtra.com/ 